Article

\title{
Calcination of Calcium Sulphoaluminate Cement Using Pyrite-Rich Cyanide Tailings
}

\author{
Kaiwei Dong ${ }^{1}$, Feng Xie ${ }^{1, *}$, Wei Wang ${ }^{1, *}$, Yongfeng Chang ${ }^{1}$, Chunlin Chen ${ }^{2}$ and Xiaowei Gu ${ }^{3}$ \\ 1 School of Metallurgy, Northeastern University, 3-11 Wenhua Road, Shenyang 110004, China; \\ 1710537@stu.neu.edu.cn (K.D.); changyf@smm.neu.edu.cn (Y.C.) \\ 2 CSIRO Minerals Resources, Clayton, VIC 3168, Australia; chunlin.chen@csiro.au \\ 3 Science and Technology Innovation Center of Smart Water and Resource Environment, Northeastern \\ University, 3-11 Wenhua Road, Shenyang 110004, China; guxiaowei@mail.neu.edu.cn \\ * Correspondence: xief@smm.neu.edu.cn (F.X.); wangwei@smm.neu.edu.cn (W.W.); \\ Tel.: +86-24-8367-2298 (F.X. \& W.W.)
}

Received: 23 September 2020; Accepted: 23 October 2020; Published: 26 October 2020

\begin{abstract}
Pyrite-rich cyanide tailings (CTs) are industrial hazardous solid wastes arising from the gold mining industry. Every year, hundreds of millions of tons of cyanide tailings are produced and discharged to tailings dams. It is of great significance to dispose of cyanide tailings harmlessly and resourcefully. The feasibility of calcination of calcium sulphoaluminate (CSA) cement clinker using pyrite-rich cyanide tailings as $\mathrm{Fe}_{2} \mathrm{O}_{3}$ and $\mathrm{SO}_{3}$ sources was investigated for this paper. The behavior of pyrite during the calcination of cyanide tailings under various calcination conditions and the properties of calcium sulphoaluminate cement clinker were examined. The results show that it is feasible to produce calcium sulphoaluminate cement clinker using pyrite-rich cyanide tailings. The optimal conditions for the calcination of calcium sulphoaluminate cement using pyrite-rich cyanide tailings are confirmed. During the calcination process, the cyanides decompose into carbonate, $\mathrm{CO}_{2}$, and $\mathrm{N}_{2}$. The pyrite decomposes into $\mathrm{Fe}_{2} \mathrm{O}_{3}$ and $\mathrm{SO}_{2}$, and they react with $\mathrm{CaO}$ and $\mathrm{Al}_{2} \mathrm{O}_{3}$ to form the intermediates of $\mathrm{CaSO}_{4}, 2 \mathrm{CaO} \cdot \mathrm{Fe}_{2} \mathrm{O}_{3}$, and $\mathrm{CaO} \cdot 2 \mathrm{Al}_{2} \mathrm{O}_{3}$, which further react to form $3 \mathrm{CaO} \cdot 3 \mathrm{Al}_{2} \mathrm{O}_{3} \cdot \mathrm{CaSO}_{4}, 4 \mathrm{CaO} \cdot \mathrm{Al}_{2} \mathrm{O}_{3} \cdot \mathrm{Fe}_{2} \mathrm{O}_{3}$, and $12 \mathrm{CaO} \cdot 7 \mathrm{Al}_{2} \mathrm{O}_{3}$. The calcium sulphoaluminate cement prepared by pyrite-rich cyanide tailings exhibits excellent mechanical properties and meets the compressive strength criteria of 42.5 grade calcium sulphoaluminate cement.
\end{abstract}

Keywords: calcium sulphoaluminate cement; pyrite; cyanide tailings; cement clinker

\section{Introduction}

Calcium sulphoaluminate (CSA) cement was essentially developed in China in the 1970s [1,2]. It is usually produced by limestone, clay, and bauxite in addition to natural gypsum at $1250-1350{ }^{\circ} \mathrm{C}$, about $100-200{ }^{\circ} \mathrm{C}$ lower than that for ordinary Portland cement (OPC) production [3,4]. $\mathrm{CO}_{2}$ emissions could be reduced significantly in this process because the major phase in CSA clinker is $3 \mathrm{CaO} \cdot 3 \mathrm{Al}_{2} \mathrm{O}_{3} \cdot \mathrm{CaSO}_{4}$ $\left(\mathrm{C}_{4} \mathrm{~A}_{3} \overline{\mathrm{S}}\right)$ compared to $3 \mathrm{CaO} \cdot \mathrm{SiO}_{2}$ in OPC [5]. Thus, CSA cement is considered as a sustainable and eco-friendly alternative to OPC due to the lower energy consumption and fewer $\mathrm{CO}_{2}$ emissions during the production [6].

This cement is widely used in architecture engineering, emergency maintenance, permeability resistance engineering, cement manufacturing, and other fields owing to its low alkalinity, rapid hardening, high early-age strength, high impermeability, chemical resistance/freeze-thaw corrosion, and low shrinkage $[5,7]$. However, the aluminum and sulfur sources suitable for the production of CSA cement are limited [8]. In recent years, increasing attention has been paid to the recycling of industrial by-products such as fly ash $[9,10]$, gypsum $[4,11]$, slag [12], and other solid wastes $[13,14]$ for CSA production. 
Cyanide tailings (CTs), produced from the gold cyanidation process in the gold mining industry, are one of the hazardous solid wastes [15]. It is estimated that more than 2.45 million tons of CTs are discharged to tailings dams in China every year [16]. It is required by law that CTs must be detoxified to a total cyanide concentration of less than $5 \mathrm{mg} \cdot \mathrm{L}^{-1}$ before being discharged to tailings dams; otherwise, a penalty rate of $\$ 150$ per ton is imposed in addition to the disposal fees charged by the certified solid waste disposal company [17]. Many technologies for the treatment and utilization of CTs have thus been developed $[15,18]$. Some treatment methods were implemented for CTs detoxification, such as alkali-chlorination [19], dry stack technology [20], incineration [21], the biological method [22], and natural degradation [23]. However, these methods may have problems of uncertain effects, the formation of toxic intermediates, limited capacity, and large occupation area, and the detoxified cyanide tailings need further care. The methods of backfilling [24] and reclamation of land [25] are also used for the disposal of CTs. However, high costs and strict environmental requirements may restrict their practical application [26].

Based on the content of valuable metals such as gold and silver in the CTs, various approaches on the recovery of $\mathrm{Au}$ and $\mathrm{Ag}[27,28]$ and the extraction of $\mathrm{Fe}, \mathrm{S}, \mathrm{Pb}-\mathrm{Zn}$, and $\mathrm{Cu}$ [29-32] have been proposed. To fully utilize the "low-value content" in the CTs, such as $\mathrm{SiO}_{2}$ and $\mathrm{Al}_{2} \mathrm{O}_{3}$, some researchers have investigated the potential use of CTs for producing brick [33], glass-ceramics [34], aerated concrete [35], and Portland cement [36].

However, to the best of our knowledge, the technology on CSA cement clinker produced by pyrite-rich CTs has not been reported. In this work, the calcination process for the preparation of CSA cement clinker using pyrite-rich CTs was investigated to elucidate the calcination mechanism of pyrite-rich CTs to produce CSA cement clinker. The potential effect of operational parameters on the formation of CSA cement clinker and its compressive strength was examined in detail, including temperature and calcination time. The feasibility of recycling CTs as the cement material for mining infrastructure construction and backfilling is discussed.

\section{Materials and Methods}

\subsection{Raw Materials}

The pyrite-rich CTs used in this study were obtained from a gold mining company in Shandong Province of China. To eliminate the interference of impurities, the analytical reagents alumina and calcium carbonate, supplied by Sinopharm Chemical Reagent Co., Ltd. (Shanghai, China), were used to produce cement clinker. The pyrite-rich CTs were dehydrated at $60^{\circ} \mathrm{C}$ for $72 \mathrm{~h}$ and crushed to below $58 \mu \mathrm{m}$ in particle size. Calcium carbonate was calcined at $1050^{\circ} \mathrm{C}$ for $240 \mathrm{~min}$ to prepare $\mathrm{CaO}$ as a raw material. The other chemical reagents (Shanghai, China) used in this work were of analytical grade.

\subsection{Experimental Procedure}

The main phases of ordinary CSA cement clinker are $\mathrm{C}_{4} \mathrm{~A}_{3} \overline{\mathrm{S}}, 4 \mathrm{CaO} \cdot \mathrm{Al}_{2} \mathrm{O}_{3} \cdot \mathrm{Fe}_{2} \mathrm{O}_{3}\left(\mathrm{C}_{4} \mathrm{AF}\right)$, and $2 \mathrm{CaO} \cdot \mathrm{SiO}_{2}$ [2]. Therefore, the designed mineral composition of the cement clinker was $\mathrm{C}_{4} \mathrm{~A}_{3} \overline{\mathrm{S}}, \mathrm{C}_{4} \mathrm{AF}$, $2 \mathrm{CaO} \cdot \mathrm{SiO}_{2}$ (if any), and $\mathrm{CaO} \cdot \mathrm{TiO}_{2}$ (if any). About $5 \mathrm{~g}$ of $\mathrm{CTs}$ were weighed, and the proportion of $\mathrm{CaO}$ and $\mathrm{Al}_{2} \mathrm{O}_{3}$ was determined by Equations (1) and (2) [37]. The alkalinity modulus $\left(\mathrm{C}_{\mathrm{m}}\right)$ was 1.00 , and the alumina-sulfur ratio $(\mathrm{P})$ was 3.82 . These raw materials were then uniformly mixed in a ball mill for $3 \mathrm{~h}$. After homogenization, the mixture was cold isostatically pressed at $15 \mathrm{MPa}$ to produce cylindrical samples with a diameter and height of 20 and $25 \mathrm{~mm}$, respectively. The cylinders were calcined in a programmable resistance furnace (Shanghai, China) from room temperature to the setting temperature (900-1450 ${ }^{\circ} \mathrm{C}$ ) at a heating rate of $10^{\circ} \mathrm{C} \mathrm{min}^{-1}$ in air. According to the literature [4], after calcining at the setting temperature for setting time, the cement clinker was taken out immediately and cooled 
down in air. The mixture and clinker were weighed and the values recorded. The cooled clinker was ground to a particle size of less than $58 \mu \mathrm{m}$ for the following analysis:

$$
\begin{gathered}
\mathrm{C}_{\mathrm{m}}=\left(\mathrm{CaO}-0.7 \mathrm{TiO}_{2}\right) /\left[1.87 \mathrm{SiO}_{2}+0.73\left(\mathrm{Al}_{2} \mathrm{O}_{3}-0.64 \mathrm{Fe}_{2} \mathrm{O}_{3}\right)+1.40 \mathrm{Fe}_{2} \mathrm{O}_{3}\right] \\
\mathrm{P}=\left(\mathrm{Al}_{2} \mathrm{O}_{3}-0.64 \mathrm{Fe}_{2} \mathrm{O}_{3}\right) / \mathrm{SO}_{3}
\end{gathered}
$$

\subsection{Analysis}

The chemical composition of $\mathrm{CaO}$ and $\mathrm{S}$ in the mixture and cement clinker were determined by inductively coupled plasma optical emission spectroscopy (Agilent 7800, Agilent Technologies Inc., Santa Clara, CA, USA) and a carbon/sulfur analyzer (SC 114DR, LECO, St. Joseph County, MI, USA), respectively. The free $\mathrm{CaO}(\mathrm{f}-\mathrm{CaO})$ in the cement clinker was analyzed according to a Chinese standard of GB/T 176-2008 [38]. The total cyanides in the CTs and cement clinker were analyzed according to a Chinese standard of HJ 745-2015 [39].

The phase composition of the cement clinker was estimated using a PW 3040/60 (PANalytical, Netherlands) with $\mathrm{Cu}-\mathrm{K} \alpha$ radiation. The diffractometer was conducted at $45 \mathrm{kV}$ and $40 \mathrm{~mA}$ with a scanning rate of $5^{\circ} \cdot \mathrm{min}^{-1}$ and a range of $5^{\circ}-80^{\circ}(2 \theta)$. Each powdered sample was evenly placed onto a rectangular steel holder, flattened with a glass slide. The data was analyzed by Jade 6.0 (MDI, USA) using the PDF2-2004 database. The Rietveld quantitative analysis of the mineralogical composition of the CSA cement clinker was determined by the internal standard method with $15.0 \% \mathrm{MgO}$ addition.

The cement clinker was then mixed with $30 \%$ calcium sulfate dihydrate (analytical reagent) to produce CSA cement. The cement slurry was prepared at a water-to-blinder ratio of 0.50 . After stirring for $4 \mathrm{~min}$ in a mechanical mixer (NJ-160, Huaxi Building Materials Testing Inc., Wuxi, Jiangsu, China), the paste was filled into $20 \times 20 \times 20 \mathrm{~mm}^{3}$ steel molds and compacted. The fresh samples were covered with a polyethylene sheet to prevent evaporation. Subsequently, the samples were demolded and cured in water at $20 \pm 1{ }^{\circ} \mathrm{C}$ [40]. Thereafter, the compressive strength of different hardened samples with curing ages of 1,3, and 28 days was measured using an HM-5030.3F (Humboldt, USA) at a speed of $7 \mathrm{~mm} / \mathrm{min}$. Four specimens were tested for each condition.

\subsection{Calculation}

The mass ratio of the cement clinker to the mixture $\left(w_{\mathrm{c} / \mathrm{m}}\right)$ was determined based on the discrepancy between the initial and remnant masses. The decomposition ratio of $S$ in the mixture $\left(\eta_{S}\right)$ was calculated based on the chemical composition of $S$ in the mixture and cement clinker.

$$
\begin{gathered}
w_{\mathrm{c} / \mathrm{m}}=m_{\mathrm{c}} / m_{\mathrm{m}} \times 100 \% \\
\eta_{\mathrm{S}}=\left(m_{\mathrm{m}} \times w_{\mathrm{m}}-m_{\mathrm{c}} \times w_{\mathrm{c}}\right) /\left(m_{\mathrm{m}} \times w_{\mathrm{m}}\right) \times 100 \%
\end{gathered}
$$

where

$m_{\mathrm{m}}$ is the mass of the mixture;

$m_{\mathrm{c}}$ is the mass of the cement clinker;

$w_{\mathrm{c} / \mathrm{m}}$ is the mass ratio of the cement clinker to the mixture;

$w_{\mathrm{m}}$ is the mass ratio of $\mathrm{S}$ in the mixture;

$w_{\mathrm{c}}$ is the mass ratio of $\mathrm{S}$ in the cement clinker.

\section{Results and Discussion}

\subsection{Characterization of the Raw Materials}

The chemical compositions of the pyrite-rich CTs, calcium carbonate, and alumina are listed in Table 1 . The mineral phases of the pyrite-rich CTs, analyzed by X-ray diffraction (XRD), are shown 
in Figure 1a. According to Table 1 and Figure 1a, the main components of the CTs are pyrite $\left(\mathrm{FeS}_{2}\right)$, quartz $\left(\mathrm{SiO}_{2}\right)$ as well as minor muscovite with a total cyanide of $339 \mathrm{mg} \cdot \mathrm{kg}^{-1}$. Analysis of $\mathrm{Al}_{2} \mathrm{O}_{3}$ by X-ray diffraction (Figure $1 \mathrm{~b}$ ) reveals that the diffraction peaks of $\mathrm{Al}_{2} \mathrm{O}_{3}$ are poor, which is believed to be attributed to the amorphous state of $\mathrm{Al}_{2} \mathrm{O}_{3}$. The analytical reagent of calcium carbonate contains $55.91 \% \mathrm{CaO}$, whereas that of alumina mainly consists of $94.60 \% \mathrm{Al}_{2} \mathrm{O}_{3}$ and $5.09 \%$ loss on ignition (LOI).

Table 1. Chemical composition of raw materials (wt \%).

\begin{tabular}{cccccccc}
\hline Raw Materials & Total Fe & $\mathrm{S}$ & $\mathrm{SiO}_{2}$ & $\mathrm{CaO}$ & $\mathrm{Al}_{2} \mathrm{O}_{3}$ & LOI & Total Cyanide \\
\hline Cyanide tailings & 41.41 & 48.40 & 5.72 & 0.47 & 1.48 & - & $339.14 \times 10^{-6}$ \\
Calcium & $<0.01$ & $<0.01$ & 0.01 & 55.91 & 0.01 & 43.88 & - \\
carbonate & 0.01 & 0.02 & 0.04 & 0.02 & 94.60 & 5.09 & - \\
Alumina & 0.01 &
\end{tabular}

Note: LOI, loss on ignition.
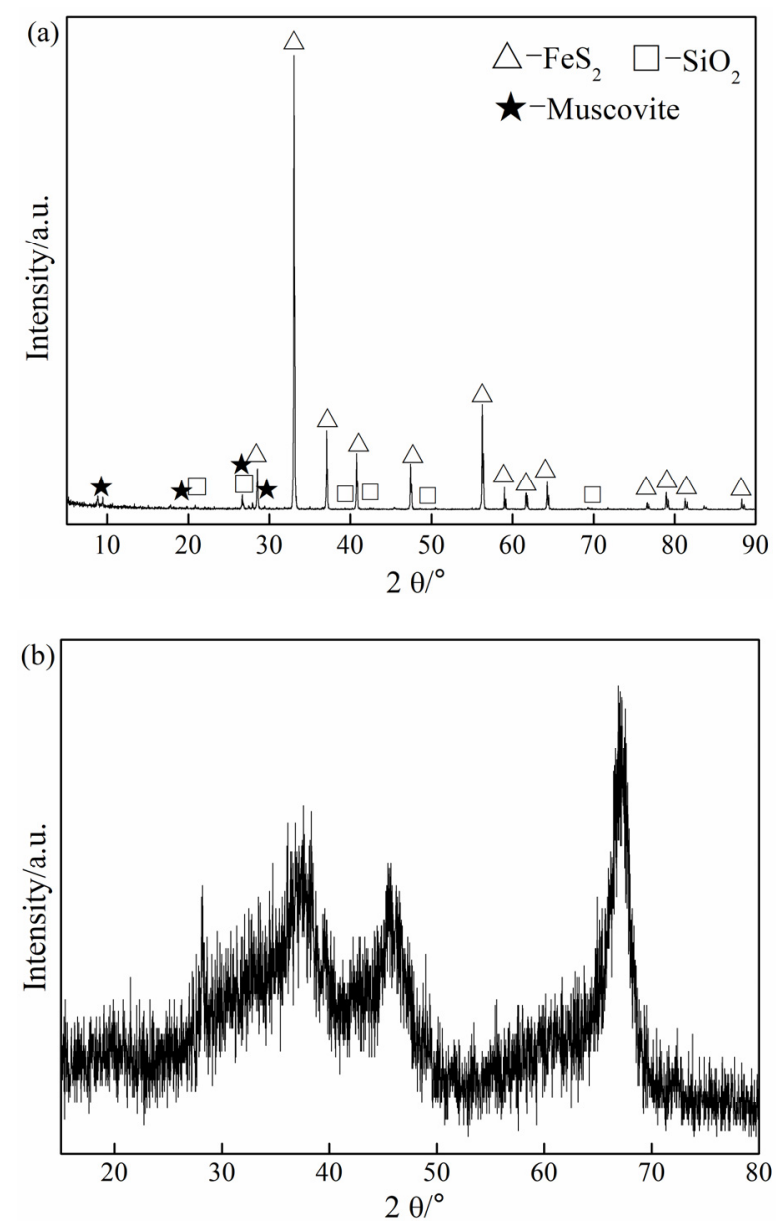

Figure 1. X-ray diffraction (XRD) pattern of (a) pyrite-rich cyanide tailings and (b) $\mathrm{Al}_{2} \mathrm{O}_{3}$.

\subsection{Compressive Strength of the Cement Clinker}

According to reaction (5), the phase of $\mathrm{C}_{4} \mathrm{~A}_{3} \overline{\mathrm{S}}$ in the cement clinker reacts rapidly with water $(\mathrm{H})$ and $\mathrm{CaSO}_{4} \cdot 2 \mathrm{H}_{2} \mathrm{O}\left(\mathrm{C} \overline{\mathrm{S}} \mathrm{H}_{2}\right)$ to form $3 \mathrm{CaO} \cdot \mathrm{Al}_{2} \mathrm{O}_{3} \cdot 3 \mathrm{CaSO}_{4} \cdot 32 \mathrm{H}_{2} \mathrm{O}(\mathrm{AFt})$ and $\mathrm{Al}(\mathrm{OH})_{3}\left(\mathrm{AH}_{3}\right)$, which play important roles in the early-age strength development [4]. The calcination temperature and time directly affect the performance of cement clinker [2]. The influence of calcination temperature and calcination time on the compressive strength of the cement clinker was explored at $1250-1350{ }^{\circ} \mathrm{C}$ for 40-80 min. The compressive strength of the cement clinker calcined under various conditions at 
different curing ages is shown in Figure 2, including that of CSA cement labeled with 42.5 grade (42.5 CSA) in Chinese standard GB/T 20472-2006.
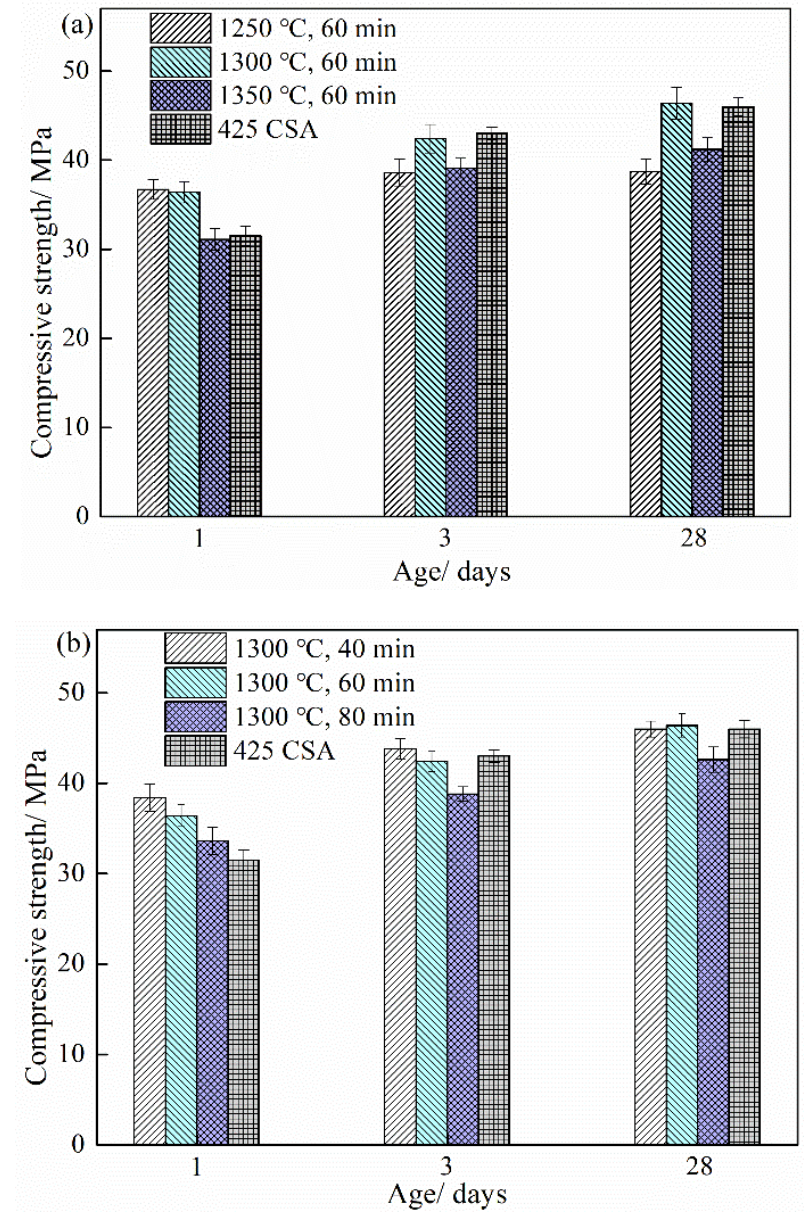

Figure 2. Compressive strength of the cement clinker calcined (a) at $1250-1350{ }^{\circ} \mathrm{C}$ for $60 \mathrm{~min}$ and (b) at $1300{ }^{\circ} \mathrm{C}$ for $40-80 \mathrm{~min}$.

Figure 2a shows that the compressive strength of the cement clinker increases with the increase in curing ages. When the calcination temperature rises from $1250{ }^{\circ} \mathrm{C}$ to $1300{ }^{\circ} \mathrm{C}$, the compressive strength of the cement clinker at the same curing ages increases, but decreases dramatically as the temperature rises to $1350{ }^{\circ} \mathrm{C}$. According to L. W. et al. [41], it is believed that $\mathrm{C}_{4} \mathrm{~A}_{3} \overline{\mathrm{S}}$ is not formed completely at low temperature, and the crystal particle of $\mathrm{C}_{4} \mathrm{~A}_{3} \overline{\mathrm{S}}$ is larger at high temperature, leading to the deterioration of the cement clinker's activity. The compressive strength of the cement clinker calcined at $1300{ }^{\circ} \mathrm{C}$ is similar to that of $42.5 \mathrm{CSA}$. This suggests that the optimal calcination temperature is determined to be $1300{ }^{\circ} \mathrm{C}$ and the compressive strength of the cement clinker meets the requirements of $42.5 \mathrm{CSA}$. In Figure $2 b$, the compressive strength of the cement clinker increases with the increase in curing ages. With the prolongation of calcination time, the compressive strength of the cement clinker decreases at the curing ages of 1 and 3 days, but remains almost constant first and then decreases at the curing age of 28 days. This suggests that the cement clinker's activity decreases with the extension of calcination time. The compressive strength of the cement clinker calcined at $1300{ }^{\circ} \mathrm{C}$ for $40-60$ min meets the requirements of $42.5 \mathrm{CSA}$. This suggests that the cement clinker meeting the compressive strength requirements of $42.5 \mathrm{CSA}$ can be obtained at $1300^{\circ} \mathrm{C}$ for $40-60 \mathrm{~min}$.

$$
\mathrm{C}_{4} \mathrm{~A}_{3} \overline{\mathrm{S}}+2 \mathrm{C} \overline{\mathrm{S}} \mathrm{H}_{2}+34 \mathrm{H} \rightarrow \mathrm{AFt}+2 \mathrm{AH}_{3}
$$




\subsection{Behavior of Pyrite in CTs During Calcination}

To investigate the behavior of pyrite in CTs during the production of CSA cement clinker, a series of experiments were conducted at $900-1300{ }^{\circ} \mathrm{C}$ without retention time. Cyanides were not detected in all samples. According to the results of previous research [42], it is believed that the cyanides in CTs decompose into carbonate, $\mathrm{CO}_{2}$, and $\mathrm{N}_{2}$ during the calcination process. The other results are displayed in Figure 3. As shown in Figure $3 \mathrm{a}, w_{\mathrm{c} / \mathrm{m}}$ is more than $100 \%$ in all cases and decreases slightly with increasing temperature, indicating that during the calcination process the pyrite in CTs is oxidized [43]. The increase of $\eta_{S}$ with increasing temperature suggests that some of the formed sulfur-containing components decompose at higher temperatures. The mass ratio of $\mathrm{f}-\mathrm{CaO}$ in the samples decreases with the increase in temperature, indicating that more and more $\mathrm{f}-\mathrm{CaO}$ is involved in the formation of cement clinker. When the mixture calcined at $1300^{\circ} \mathrm{C}$ without retention time, $4 \%$ of $\mathrm{f}-\mathrm{CaO}$ was detected in the sample, indicating that the reaction between $\mathrm{f}-\mathrm{CaO}$ and the pyrite-rich $\mathrm{CTs}$ is still incomplete [6].
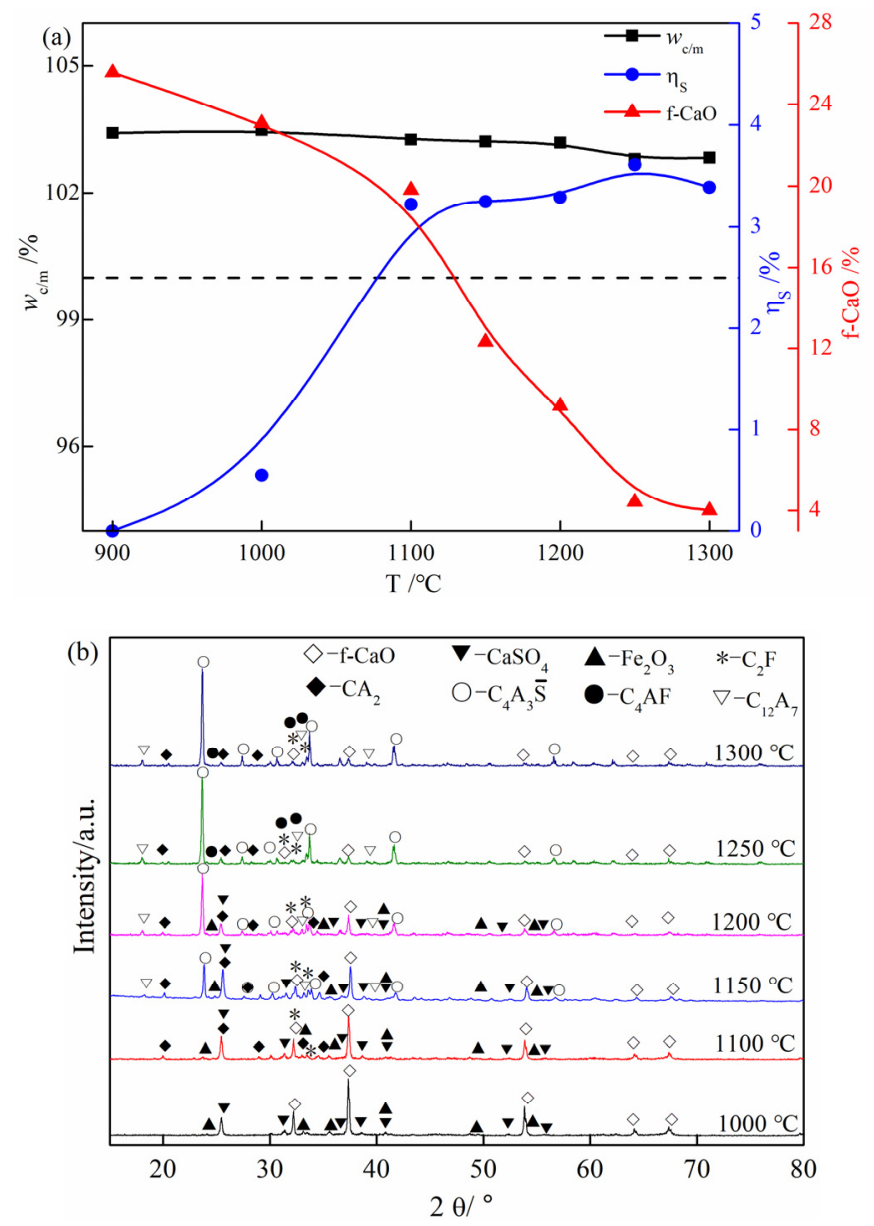

Figure 3. (a) Variation of the mass of the cement clinker to the mixture $\left(w_{\mathrm{c} / \mathrm{m}}\right)$, the decomposition ratio of $S$ for the mixture $\left(\eta_{\mathrm{S}}\right)$, and the mass ratio of free $\mathrm{CaO}(\mathrm{f}-\mathrm{CaO})$ in the cement clinker versus temperature at $900-1300{ }^{\circ} \mathrm{C}$ without retention time; (b) XRD patterns of the cement clinker calcined at $1000-1300{ }^{\circ} \mathrm{C}$ without retention time.

Figure $3 \mathrm{~b}$ shows that the phase composition of the clinker varies greatly at different temperatures. The diffraction peaks of $\mathrm{Al}_{2} \mathrm{O}_{3}$ are absent in all samples as it is amorphous. The sample calcined at $1000{ }^{\circ} \mathrm{C}$ consists of $\mathrm{Fe}_{2} \mathrm{O}_{3}, \mathrm{CaSO}_{4}$, and $\mathrm{f}-\mathrm{CaO}$, suggesting that $\mathrm{FeS}_{2}$ reacts with $\mathrm{O}_{2}$ and $\mathrm{f}-\mathrm{CaO}$ to form $\mathrm{Fe}_{2} \mathrm{O}_{3}$ and $\mathrm{CaSO}_{4}$ by reactions (6) and (7). New phases of $\mathrm{CaO} \cdot 2 \mathrm{Al}_{2} \mathrm{O}_{3}\left(\mathrm{CA}_{2}\right)$ and $2 \mathrm{CaO} \cdot \mathrm{Fe}_{2} \mathrm{O}_{3}\left(\mathrm{C}_{2} \mathrm{~F}\right)$ are presented at $1100{ }^{\circ} \mathrm{C}$, indicating that reactions (8) and (9) occur at $1100{ }^{\circ} \mathrm{C}_{,} \mathrm{C}_{4} \mathrm{~A}_{3} \overline{\mathrm{S}}$ and $12 \mathrm{CaO} \cdot 7 \mathrm{Al}_{2} \mathrm{O}_{3}$ $\left(\mathrm{C}_{12} \mathrm{~A}_{7}\right)$ are observed at $1150{ }^{\circ} \mathrm{C}$, and the diffraction intensity of $\mathrm{CA}_{2}$ and $\mathrm{CaSO}_{4}$ decreases rapidly 
over $1150{ }^{\circ} \mathrm{C}$. This suggests that the reactions (10)-(12) occur over $1150{ }^{\circ} \mathrm{C}$. When the mixture calcines at 1250 or $1300^{\circ} \mathrm{C}$, the clinker is composed of $\mathrm{C}_{4} \mathrm{~A}_{3} \overline{\mathrm{S}}, \mathrm{C}_{4} \mathrm{AF}, \mathrm{CA}_{2}, \mathrm{C}_{12} \mathrm{~A}_{7}$, and $\mathrm{C}_{2} \mathrm{~F}$. As the calcination temperature increases, the diffraction intensity of $\mathrm{Fe}_{2} \mathrm{O}_{3}$ and $\mathrm{CaSO}_{4}$ gradually decreases but disappears at $1250{ }^{\circ} \mathrm{C}$, whereas that of $\mathrm{f}-\mathrm{CaO}$ decreases sharply. This suggests that reactions (9)-(11) are almost complete. The diffraction intensity of $\mathrm{CA}_{2}$ increases first and then decreases, whereas that of $\mathrm{C}_{4} \mathrm{~A}_{3} \overline{\mathrm{S}}$ and $C_{12} A_{7}$ increases substantially with increasing temperature, meaning that $C_{2}$ is formed as an intermediate, and the increase in temperature facilitates the reactions (8) and (10)-(12). The diffraction intensity of $\mathrm{C}_{2} \mathrm{~F}$ decreases gradually and nearly disappears, whereas that of $\mathrm{C}_{4} \mathrm{AF}$ remains almost constant above $1250^{\circ} \mathrm{C}$. It suggests that $\mathrm{C}_{2} \mathrm{~F}$ is also formed as an intermediate, and higher temperatures promote reactions (13) and (14).

$$
\begin{gathered}
4 \mathrm{FeS}_{2}+11 \mathrm{O}_{2} \rightarrow 2 \mathrm{Fe}_{2} \mathrm{O}_{3}+8 \mathrm{SO}_{2} \uparrow \\
2 \mathrm{CaO}+2 \mathrm{SO}_{2}+\mathrm{O}_{2} \rightarrow 2 \mathrm{CaSO}_{4} \\
\mathrm{CaO}+2 \mathrm{Al}_{2} \mathrm{O}_{3} \rightarrow \mathrm{CaO} \cdot 2 \mathrm{Al}_{2} \mathrm{O}_{3} \\
2 \mathrm{CaO}+\mathrm{Fe}_{2} \mathrm{O}_{3} \rightarrow 2 \mathrm{CaO} \cdot \mathrm{Fe}_{2} \mathrm{O}_{3} \\
3 \mathrm{CaO}+3\left(\mathrm{CaO} \cdot 2 \mathrm{Al}_{2} \mathrm{O}_{3}\right)+2 \mathrm{CaSO}_{4} \rightarrow 2\left(3 \mathrm{CaO} \cdot 3 \mathrm{Al}_{2} \mathrm{O}_{3} \cdot \mathrm{CaSO}_{4}\right) \\
3 \mathrm{CaO}+3 \mathrm{Al}_{2} \mathrm{O}_{3}+\mathrm{CaSO}_{4} \rightarrow 3 \mathrm{CaO} \cdot 3 \mathrm{Al}_{2} \mathrm{O}_{3} \cdot \mathrm{CaSO}_{4} \\
17 \mathrm{CaO}+7\left(\mathrm{CaO} \cdot 2 \mathrm{Al}_{2} \mathrm{O}_{3}\right) \rightarrow 2\left(12 \mathrm{CaO} \cdot 7 \mathrm{Al}_{2} \mathrm{O}_{3}\right) \\
2 \mathrm{CaO}+\mathrm{Al}_{2} \mathrm{O}_{3}+2 \mathrm{CaO} \cdot \mathrm{Fe}_{2} \mathrm{O}_{3} \rightarrow 4 \mathrm{CaO} \cdot \mathrm{Al}_{2} \mathrm{O}_{3} \cdot \mathrm{Fe}_{2} \mathrm{O}_{3} \\
3 \mathrm{CaO}+\mathrm{CaO} \cdot 2 \mathrm{Al}_{2} \mathrm{O}_{3}+2\left(2 \mathrm{CaO} \cdot \mathrm{Fe}_{2} \mathrm{O}_{3}\right) \rightarrow 2\left(4 \mathrm{CaO} \cdot \mathrm{Al}_{2} \mathrm{O}_{3} \cdot \mathrm{Fe}_{2} \mathrm{O}_{3}\right)
\end{gathered}
$$

\subsection{Preparation of the Cement Clinker}

\subsubsection{Effect of Calcination Temperature}

The effect of calcination temperature on the preparation of the cement clinker was investigated by maintaining the mixture at $1200-1450{ }^{\circ} \mathrm{C}$ for $60 \mathrm{~min}$. The results (Figure $4 \mathrm{a}$ ) show that $w_{\mathrm{c} / \mathrm{m}}$ is more than $100 \%$ in all cases and gradually decreases with the increase in temperature. This indicates that the oxidation of pyrite-rich CTs increases the mass of cement clinker. The increase of $\eta_{S}$ with the rise in temperature indicates that higher temperatures promote the loss of sulfur in clinker. The mass ratio of $\mathrm{f}-\mathrm{CaO}$ in clinker decreases rapidly with the rise in temperature, suggesting that higher temperatures facilitate the reactions in which $\mathrm{f}-\mathrm{CaO}$ is consumed.

\subsubsection{Effect of Calcination Time}

The effect of calcination time on the preparation of the cement clinker was explored at $1300{ }^{\circ} \mathrm{C}$ for $0-80 \mathrm{~min}$. The results presented in Figure $4 \mathrm{~b}$ show that $w_{\mathrm{c} / \mathrm{m}}$ is greater than $100 \%$ in all cases, and decreases slightly with the increase in calcination time. $\eta_{S}$ increases gradually, whereas the mass ratio of $\mathrm{f}-\mathrm{CaO}$ decreases rapidly with the prolongation of reaction time. The mass ratio of $\mathrm{f}-\mathrm{CaO}$ is undetected as the calcination time is above $40 \mathrm{~min}$. This suggests that longer calcination time contributes to the loss of sulfur and the consumption of f-CaO in clinker, and favors reactions (13) and (14). 

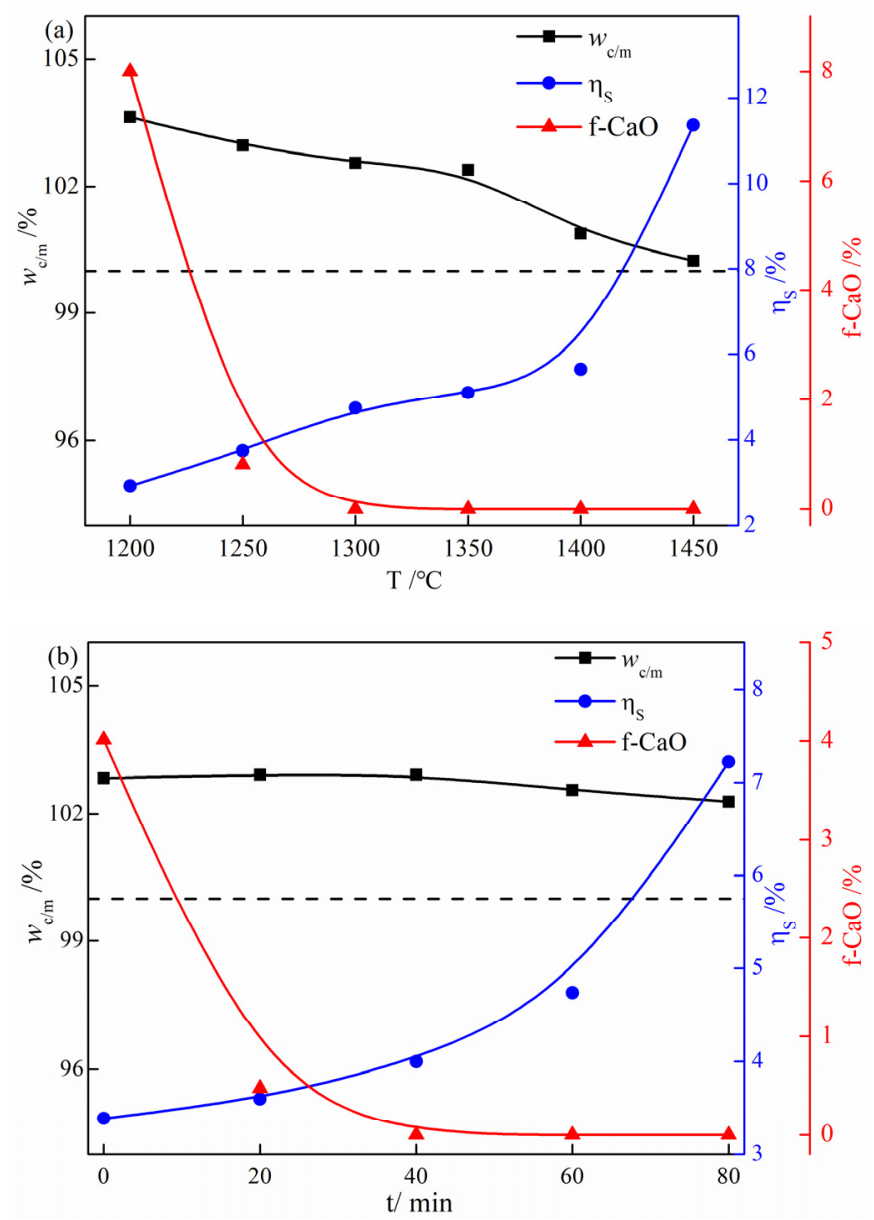

Figure 4. Variation of the mass of the cement clinker to the mixture $\left(w_{\mathrm{c} / \mathrm{m}}\right)$, the decomposition ratio of $\mathrm{S}$ for the mixture $\left(\eta_{S}\right)$, and the mass ratio of free $\mathrm{CaO}(\mathrm{f}-\mathrm{CaO})$ in the cement clinker versus (a) temperature at $1200-1450{ }^{\circ} \mathrm{C}$ for $60 \mathrm{~min}$ and (b) calcination time at $1300{ }^{\circ} \mathrm{C}$ for $0-80 \mathrm{~min}$.

\subsection{Mineral Phases of the Cement Clinker}

\subsubsection{XRD Patterns at Different Calcination Temperatures}

The XRD patterns of the cement clinker calcined at $1250-1400{ }^{\circ} \mathrm{C}$ for $60 \mathrm{~min}$ are shown in Figure $5 \mathrm{a}$. It shows that $\mathrm{C}_{4} \mathrm{~A}_{3} \overline{\mathrm{S}}, \mathrm{C}_{4} \mathrm{AF}$, and $\mathrm{C}_{12} \mathrm{~A}_{7}$, which are favorable phases in normal CSA cement clinker [44], occur at all cement clinker phases. $\mathrm{CA}_{2}$ and $\mathrm{C}_{2} \mathrm{~F}$ are found in the clinker calcined at $1250{ }^{\circ} \mathrm{C}$ for $60 \mathrm{~min}$. The major phases of the cement clinker calcined above $1300^{\circ} \mathrm{C}$ for 60 min are $\mathrm{C}_{4} \mathrm{~A}_{3} \overline{\mathrm{S}}, \mathrm{C}_{4} \mathrm{AF}$, and $\mathrm{C}_{12} \mathrm{~A}_{7}$, suggesting that a higher temperature favors the decomposition of intermediates $\left(\mathrm{CA}_{2}\right.$ and $\left.\mathrm{C}_{2} \mathrm{~F}\right)$ and the formation of the desired mineral phases of CSA cement. The mineralogical composition of the cement clinker was analyzed using the Rietveld refinement method with $15.0 \% \mathrm{MgO}$ internal standard. The portable document format (PDF) and inorganic crystal structure database (ICSD) codes of mineral phases for quantitative analysis are listed in Table 2, and the refinement results are listed in Table 3. When the mixture calcined at $1250{ }^{\circ} \mathrm{C}$ for $60 \mathrm{~min}, 1.9 \% \mathrm{C}_{2} \mathrm{~F}$ and $5.2 \% \mathrm{CA}_{2}$ remain in clinker, while 61.2\% $\mathrm{C}_{4} \mathrm{~A}_{3} \overline{\mathrm{S}}$ and 7.4\% $\mathrm{C}_{4} \mathrm{AF}$ are formed. $\mathrm{C}_{2} \mathrm{~F}$ and $\mathrm{CA}_{2}$ disappear at higher temperatures, indicating that reaction (14) happens. The content of $\mathrm{C}_{4} \mathrm{~A}_{3} \overline{\mathrm{S}}$ increases with the rise in temperature, while that of $\mathrm{C}_{4} \mathrm{AF}$ increases considerably, and that of $\mathrm{C}_{12} \mathrm{~A}_{7}$ decreases. This demonstrates that a higher temperature promotes the formation of $\mathrm{C}_{4} \mathrm{~A}_{3} \overline{\mathrm{S}}$ and $\mathrm{C}_{4} \mathrm{AF}$, but causes the decomposition of $\mathrm{C}_{12} \mathrm{~A}_{7}$. 

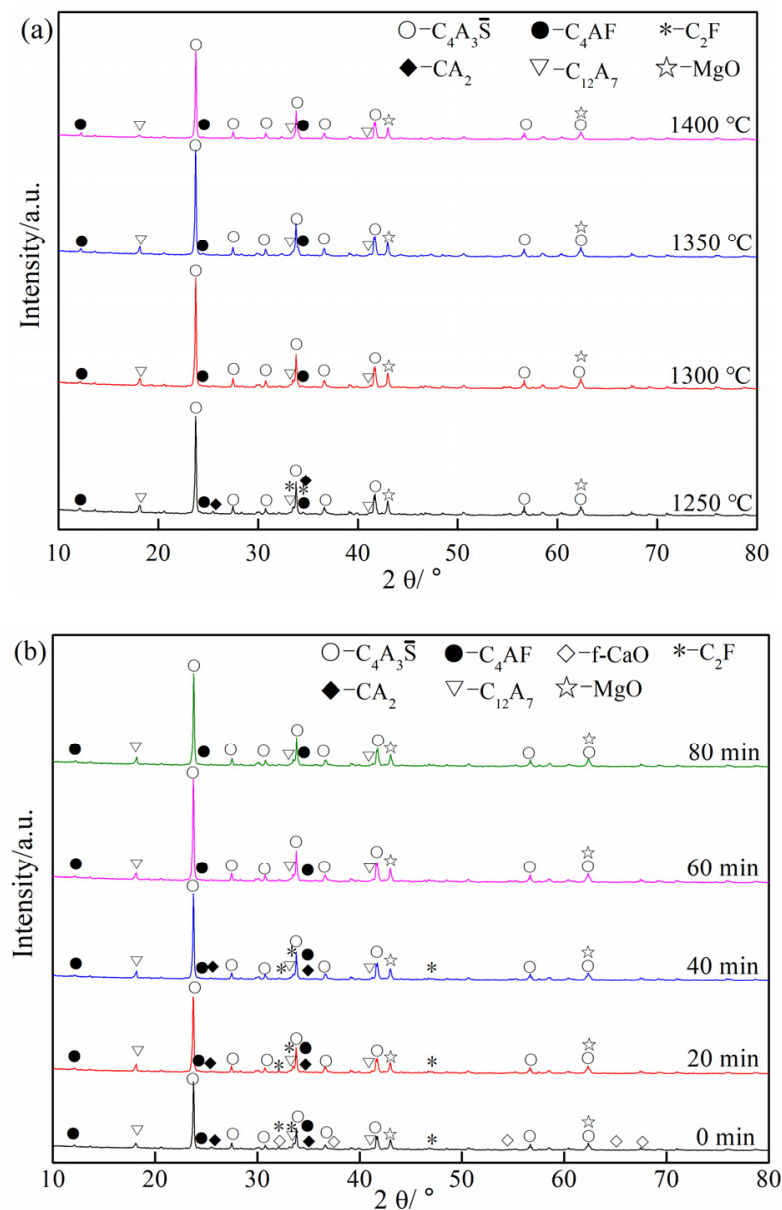

Figure 5. XRD patterns of the cement clinker calcined (a) at $1250-1400{ }^{\circ} \mathrm{C}$ for $60 \mathrm{~min}$ and (b) at $1300{ }^{\circ} \mathrm{C}$ for $0-80 \mathrm{~min}$.

Table 2. The portable document format (PDF) and the inorganic crystal structure database (ICSD) codes of mineral phases used for Rietveld refinement.

\begin{tabular}{cccc}
\hline Mineral Phases & PDF Code & ICSD Code & References \\
\hline $\mathrm{C}_{4} \mathrm{~A}_{3} \overline{\mathrm{S}}$ & $85-2210$ & 80361 & {$[45]$} \\
$\mathrm{C}_{4} \mathrm{AF}$ & $74-1346$ & 27112 & {$[46]$} \\
$\mathrm{C}_{12} \mathrm{~A}_{7}$ & $70-2144$ & 6287 & {$[47]$} \\
$\mathrm{C}_{2} \mathrm{~F}$ & $71-2264$ & 15059 & {$[48]$} \\
$\mathrm{CA}_{2}$ & $89-3851$ & 44519 & {$[49]$} \\
$\mathrm{f}-\mathrm{CaO}$ & $78-0649$ & 61550 & {$[50]$} \\
$\mathrm{MgO}$ & $78-0430$ & 61325 & {$[51]$} \\
\hline
\end{tabular}

Table 3. Mineralogical composition of the cement clinker calcined at $1250-1400{ }^{\circ} \mathrm{C}$ for $60 \mathrm{~min}$ by Rietveld refinement with $15.0 \% \mathrm{MgO}$ internal standard (wt \%).

\begin{tabular}{cccccccc}
\hline $\mathbf{T} /{ }^{\circ} \mathbf{C}$ & $\mathbf{C}_{4} \mathbf{A}_{3} \overline{\mathbf{S}}$ & $\mathbf{C}_{\mathbf{4}} \mathbf{A F}$ & $\mathbf{C}_{\mathbf{1 2}} \mathbf{A}_{\mathbf{7}}$ & $\mathbf{C}_{\mathbf{2}} \mathbf{F}$ & $\mathbf{C A}_{\mathbf{2}}$ & $\mathbf{M g O}$ & $\mathbf{R}$ \\
\hline 1250 & 61.2 & 7.4 & 9.3 & 1.9 & 5.2 & 14.9 & 8.96 \\
1300 & 64.1 & 11.0 & 9.4 & - & - & 15.3 & 8.08 \\
1350 & 65.6 & 12.4 & 7.1 & - & - & 14.9 & 8.14 \\
1400 & 68.8 & 13.5 & 2.9 & - & - & 14.8 & 9.21 \\
\hline
\end{tabular}

Note: R, weighted residual error of refinement. 


\subsubsection{XRD Patterns at Different Calcination Times}

The cement clinker calcined at $1300^{\circ} \mathrm{C}$ for 0-80 min was analyzed by XRD. As shown in Figure $5 b$, $\mathrm{C}_{4} \mathrm{~A}_{3} \overline{\mathrm{S}}, \mathrm{C}_{4} \mathrm{AF}$, and $\mathrm{C}_{12} \mathrm{~A}_{7}$ are present in all cement clinker phases. F-CaO is observed at the free retention time of $1300{ }^{\circ} \mathrm{C}$, but disappears when the calcination time exceeds 20 min, indicating that part of $\mathrm{f}-\mathrm{CaO}$ remains unreacted due to the lack of calcination time, and the reactions involving the consumption of $\mathrm{f}-\mathrm{CaO}$ are almost complete when the calcination time exceeds $20 \mathrm{~min}$. $\mathrm{CA}_{2}$ and $\mathrm{C}_{2} \mathrm{~F}$ are found in the clinker calcined at $1300^{\circ} \mathrm{C}$ for $0-40 \mathrm{~min}$, but disappear when the calcination time is above $40 \mathrm{~min}$. The major phases of the cement clinker calcined at $1300^{\circ} \mathrm{C}$ for more than $40 \mathrm{~min}$ are $\mathrm{C}_{4} \mathrm{~A}_{3} \overline{\mathrm{S}}, \mathrm{C}_{4} \mathrm{AF}$, and $\mathrm{C}_{12} \mathrm{~A}_{7}$. This indicates that the prolongation of calcination time contributes to the decomposition of $C_{2}$ and $C_{2} F$ and the formation of the desired mineral phases of $C_{4} A_{3} \bar{S}$ and $C_{4} A F$. The mineralogical composition of the cement clinker was analyzed using the Rietveld refinement method with $15.0 \% \mathrm{MgO}$ internal standard. The PDF and ICSD codes of mineral phases for quantitative analysis are listed in Table 2 , and the results are listed in Table 4 . The clinker contains $56.7 \% \mathrm{C}_{4} \mathrm{~A}_{3} \overline{\mathrm{S}}$, $7.5 \% \mathrm{C}_{4} \mathrm{AF}$, and $9.3 \% \mathrm{C}_{12} \mathrm{~A}_{7}$, as well as $3.1 \% \mathrm{C}_{2} \mathrm{~F}, 4.7 \% \mathrm{CA}_{2}$, and $3.3 \% \mathrm{f}-\mathrm{CaO}$ when the mixture calcined at $1300{ }^{\circ} \mathrm{C}$ without retention time. It implies that the reactions in cement clinker are not complete due to the lack of reaction time. F-CaO was not found at $1300{ }^{\circ} \mathrm{C}$ for $20 \mathrm{~min}$, corresponding to the results shown in Figure $4 \mathrm{~b}$. This indicates that the reactions involving $\mathrm{f}-\mathrm{CaO}$ are complete. $\mathrm{C}_{2} \mathrm{~F}$ and $\mathrm{CA}_{2}$ are absent in the cement clinker calcined at $1300{ }^{\circ} \mathrm{C}$ for more than $40 \mathrm{~min}$. The content of both $\mathrm{C}_{4} \mathrm{~A}_{3} \overline{\mathrm{S}}$ and $\mathrm{C}_{4} \mathrm{AF}$ increases significantly with calcination time, whereas that of $\mathrm{C}_{12} \mathrm{~A}_{7}$ remains quite constant. This suggests that the prolongation of the calcination time promotes the decomposition of $\mathrm{CA}_{2}$ and $\mathrm{C}_{2} \mathrm{~F}$ and the formation of $\mathrm{C}_{4} \mathrm{~A}_{3} \overline{\mathrm{S}}$ and $\mathrm{C}_{4} \mathrm{AF}$. Overall, the favorable cement clinker is obtained at $1300{ }^{\circ} \mathrm{C}$ for more than $40 \mathrm{~min}$.

Table 4. Mineralogical composition of the cement clinker calcined at $1300{ }^{\circ} \mathrm{C}$ for $0-80 \mathrm{~min}$ by Rietveld refinement with $15.0 \% \mathrm{MgO}$ internal standard (wt \%).

\begin{tabular}{ccccccccc}
\hline $\mathbf{t} / \mathbf{m i n}$ & $\mathbf{C}_{\mathbf{4}} \mathbf{A}_{3} \overline{\mathbf{S}}$ & $\mathbf{C}_{\mathbf{4}} \mathbf{A F}$ & $\mathbf{C}_{\mathbf{1 2}} \mathbf{A}_{\mathbf{7}}$ & $\mathbf{C}_{\mathbf{2}} \mathbf{F}$ & $\mathbf{C A}_{\mathbf{2}}$ & $\mathbf{C a O}$ & $\mathbf{M g O}$ & $\mathbf{R}$ \\
\hline 0 & 56.7 & 7.5 & 9.3 & 3.1 & 4.7 & 3.3 & 15.4 & 8.99 \\
20 & 62.1 & 7.5 & 9.7 & 2.3 & 3.6 & - & 14.9 & 9.30 \\
40 & 64.1 & 7.0 & 9.1 & 2.3 & 2.4 & - & 15.1 & 9.09 \\
60 & 64.1 & 11.0 & 9.4 & - & - & - & 15.3 & 8.08 \\
80 & 64.4 & 10.9 & 9.3 & - & - & - & 15.3 & 8.72 \\
\hline
\end{tabular}

Note: R, weighted residual error of refinement.

\section{Conclusions}

It is feasible to produce CSA cement clinker using pyrite-rich CTs as the sources of $\mathrm{Fe}_{2} \mathrm{O}_{3}$ and $\mathrm{SO}_{3}$. The main conclusions are summarized as follows.

The compressive strength of cement clinker is affected by calcination temperature and time, especially the calcination temperature. It meets the compressive strength criteria of 42.5 CSA when the mixture is calcined at $1300{ }^{\circ} \mathrm{C}$ for $40-60 \mathrm{~min}$.

During the calcination process, the cyanides decompose into carbonate, $\mathrm{CO}_{2}$, and $\mathrm{N}_{2}$. The pyrite is oxidized into $\mathrm{Fe}_{2} \mathrm{O}_{3}$ and $\mathrm{SO}_{2}$ below $1000{ }^{\circ} \mathrm{C}$ and they react with $\mathrm{CaO}$ and $\mathrm{Al}_{2} \mathrm{O}_{3}$ above $1000{ }^{\circ} \mathrm{C}$ to form the intermediates of $\mathrm{CaSO}_{4}, \mathrm{CF}_{2}$, and $\mathrm{CA}_{2}$, which further react to form the desired mineral phases of $\mathrm{C}_{4} \mathrm{~A}_{3} \overline{\mathrm{S}}$ and $\mathrm{C}_{4} \mathrm{AF}$.

In the production of CSA cement clinker, the mass ratio of $\mathrm{f}-\mathrm{CaO}$ and the decomposition of $\mathrm{S}$ in CSA cement clinker are influenced by calcination temperature and time. The optimal conditions are to calcine the mixture at $1300{ }^{\circ} \mathrm{C}$ for $40-60 \mathrm{~min}$.

The major mineral phases of the cement clinker calcined at $1300{ }^{\circ} \mathrm{C}$ for more than $40 \mathrm{~min}$ are $\mathrm{C}_{4} \mathrm{~A}_{3} \overline{\mathrm{S}}, \mathrm{C}_{4} \mathrm{AF}$, and $\mathrm{C}_{12} \mathrm{~A}_{7}$. 
Author Contributions: Investigation, K.D.; Writing-Original draft preparation, K.D.; Supervision, F.X.; Validation, F.X.; Resources, F.X. and Y.C.; Project administration, F.X.; Funding acquisition, F.X. and Y.C.; Writing-Reviewing, F.X., W.W., and C.C.; Visualization, W.W.; Software; W.W.; Conceptualization, C.C. and X.G.; Data curation, W.W. and X.G. All authors have read and agreed to the published version of the manuscript.

Funding: The work was funded by the National Key Research and Development Program of China (No. 2018YFC0604604), the National Natural Science Foundation of China-Yunnan Joint Fund (No. U1702252), the Fundamental Research Funds for Central Universities of China (No. N182506003), and the Key Research Program of Liaoning Province (No. 2019JH2/10300051).

Acknowledgments: The authors would like to thank Y.F., J.R., and H.L. from the Center for Experiment of the School of Metallurgy, Northeastern University, Shenyang, China, for their support. The authors gratefully acknowledge the Department of Heavy Precious Metals Metallurgy and Materials, Northeastern University, Shenyang, China. The authors would also like to thank Jiang Haiqiang, Gao Peng, Li Qi, Jie Yongshuai, Bai Yunlong, Lu Yuhe, Zhang Zhuang, and Zhang Ning for their support.

Conflicts of Interest: The authors declare no conflict of interest.

\section{References}

1. Habert, G. Assessing the environmental impact of conventional and 'green' cement production. In Eco-Efficient Construction and Building Materials; Elsevie: Amsterdam, The Netherlands, 2014; pp. 199-238.

2. Wang, Y.; Su, M.; Zhang, L. Sulphoaluminate Cement; Beijing University of Technology Press: Beijing, China, 1999.

3. Bullerjahn, F.; Schmitt, D.; Ben Haha, M. Effect of raw mix design and of clinkering process on the formation and mineralogical composition of (ternesite) belite calcium sulphoaluminate ferrite clinker. Cem. Concr. Res. 2014, 59, 87-95. [CrossRef]

4. Wu, S.; Wang, W.; Ren, C.; Yao, X.; Yao, Y.; Zhang, Q.; Li, Z. Calcination of calcium sulphoaluminate cement using flue gas desulfurization gypsum as whole calcium oxide source. Constr. Build. Mater. 2019, 228, 116676. [CrossRef]

5. Shen, Y.; Qian, J.; Chai, J.; Fan, Y. Calcium sulphoaluminate cements made with phosphogypsum: Production issues and material properties. Cem. Concr. Compos. 2014, 48, 67-74. [CrossRef]

6. Xue, P.; Xu, A.; He, D.; Yang, Q.; Liu, G.; Engström, F.; Björkman, B. Research on the sintering process and characteristics of belite sulphoaluminate cement produced by BOF slag. Constr. Build. Mater. 2016, 122, 567-576. [CrossRef]

7. Zhou, H.; Liu, J.; Liu, J.; Li, C. Hydration kinetics process of low alkalinity sulphoaluminate cement and its thermodynamical properties. Procedia Eng. 2012, 27, 323-331. [CrossRef]

8. Schneider, M.; Romer, M.; Tschudin, M.; Bolio, H. Sustainable cement production-present and future. Cem. Concr. Res. 2011, 41, 642-650. [CrossRef]

9. Mao, Y.; Wu, H.; Wang, W.; Jia, M.; Che, X. Pretreatment of municipal solid waste incineration fly ash and preparation of solid waste source sulphoaluminate cementitious material. J. Hazard. Mater. 2020, 385, 121580. [CrossRef]

10. Shen, Y.; Chen, X.; Zhang, W.; Li, X.; Qian, J. Influence of ternesite on the properties of calcium sulfoaluminate cements blended with fly ash. Constr. Build. Mater. 2018, 193, 221-229. [CrossRef]

11. Jin, Z.; Ma, B.; Su, Y.; Lu, W.; Qi, H.; Hu, P. Effect of calcium sulphoaluminate cement on mechanical strength and waterproof properties of beta-hemihydrate phosphogypsum. Constr. Build. Mater. 2020, 242, 118198. [CrossRef]

12. Gao, D.; Meng, Y.; Yang, L.; Tang, J.; Lv, M. Effect of ground granulated blast furnace slag on the properties of calcium sulfoaluminate cement. Constr. Build. Mater. 2019, 227, 116665. [CrossRef]

13. Ge, Z.; Yuan, H.; Sun, R.; Zhang, H.; Wang, W.; Qi, H. Use of green calcium sulphoaluminate cement to prepare foamed concrete for road embankment: A feasibility study. Constr. Build. Mater. 2020, 237, 117791. [CrossRef]

14. Da Costa, E.B.; Rodríguez, E.D.; Bernal, S.A.; Provis, J.L.; Gobbo, L.A.; Kirchheim, A.P. Production and hydration of calcium sulfoaluminate-belite cements derived from aluminium anodising sludge. Constr. Build. Mater. 2016, 122, 373-383. [CrossRef]

15. Lv, C.; Ding, J.; Qian, P.; Li, Q.; Ye, S.; Chen, Y. Comprehensive recovery of metals from cyanidation tailing. Miner. Eng. 2015, 70, 141-147. [CrossRef] 
16. Lei, Z.; Guangfeng, K.; Shufen, L.; Xianfeng, C.; Xianyang, W. Research on multi-element resources of utilizing cyaniding tailings. Environ. Sci. Technol. 2010, 23, 5-7.

17. Order no. 61 of the President of the People's Republic of China. Environmental Protection Tax Law of the People's Republic of China; Republic of China: Beijing, China, 2016; Chapter V.

18. Barcelos, D.A.; Pontes, F.V.; Da Silva, F.A.; Castro, D.C.; Dos Anjos, N.O.; Castilhos, Z.C. Gold mining tailing: Environmental availability of metals and human health risk assessment. J. Hazard. Mater. 2020, 397, 122721. [CrossRef]

19. Chen, X.; Zhang, C. Applying alkali-chlorination method in treatment for cyanide containing gold tailing sands. Environ. Sanit. Eng. 2009, 17, 42-44.

20. Xing, W.; Jin, Y.; Yao, X. Discussion on some issues in dry stack technology of tailings from gold mines. Nonferr. Metals (Min.) 2008, 60, 48-50.

21. Qian-jin, G. Discussion on treatment technology of cyanide waste in sodium cyanide plant. J. Shanxi Coal-Min. Adm. Col. 2004, 87-88.

22. Khamar, Z.; Makhdoumi-Kakhki, A.; Gharaie, M.M. Remediation of cyanide from the gold mine tailing pond by a novel bacterial co-culture. Int. Biodeterior. Biodegrad. 2015, 99, 123-128. [CrossRef]

23. Ritcey, G.M. Tailings management in gold plants. Hydrometallurgy 2005, 78, 3-20. [CrossRef]

24. Amaratunga, L.M.; Hmidi, N. Cold-bond agglomeration of gold mill tailings for backfill using gypsum betahemihydrate and cement as low cost binders. Can. Metal. Quart. 1997, 36, 283-288. [CrossRef]

25. Jiao, X.; Liu, X. Restoring tailing pool of gold mine to farmland. Gold 2004, 25, 46-47.

26. GB 18598-2001. Standard for Pollution Control on the Security Landfill Site for Hazardous Wastes; China Standard Press: Beijing, China, 2001; pp. 421-429.

27. Li, H.; Long, H.; Zhang, L.; Yin, S.; Li, S.; Zhu, F.; Xie, H. Effectiveness of microwave-assisted thermal treatment in the extraction of gold in cyanide tailings. J. Hazard. Mater. 2020, 384, 121456. [CrossRef]

28. Long, H.; Ma, A.; Srinivasakannan, C.; Zhang, L.; Li, S.; Yin, S. Investigation on the recovery of gold and silver from cyanide tailings using chlorination roasting process. J. Alloy. Compd. 2018, 763, 241-249. [CrossRef]

29. Zhang, Y.-L.; Li, H.-M.; Yu, X.-J. Fe extraction from high-silicon and aluminum cyanide tailings by pretreatment of water leaching before magnetic separation. Trans. Nonferrous Met. Soc. China 2013, 23, 1165-1173. [CrossRef]

30. Yang, X.; Huang, X.; Qiu, T. Recovery of zinc from cyanide tailings by flotation. Miner. Eng. 2015, 84, 100-105. [CrossRef]

31. Zhang, M.; Cao, Y.; Peng, B.; Tian, Y.; Barvor, J.B. Removal of copper cyanide by precipitate flotation with ammonium salts. Process. Saf. Environ. Prot. 2020, 133, 82-87. [CrossRef]

32. Junfeng, G.; Xiaobo, L. Utilization of cyanided tailings from gold ore dressing plant. Miner. Eng. 2005, 3, 38-39.

33. Roy, S.; Adhikari, G.R.; Gupta, R.N. Use of gold mill tailings in making bricks: A feasibility study. Waste Manag. Res. 2007, 25, 475-482. [CrossRef]

34. Shao, H.; Liang, K.; Peng, F.; Zhou, F.; Hu, A. Production and properties of cordierite-based glass-ceramics from gold tailings. Miner. Eng. 2005, 18, 635-637. [CrossRef]

35. Ding, Y.; Wu, W. Preparation of aerated concrete block by making use of the gold tailings. New Build. Mater. 2009, 38-40. [CrossRef]

36. Qiu, Y.; Zhao, Y. Utilization of metal mine solid waste in production of construction materials. Nonferr. Metal Eng. Res. 2008, 29, 35-38.

37. Zhang, S.; Shuai, G. Charge calculation of sulfoaluminate belite cement clinker. J. Nanchang Univ. (Eng. Technol.) 2011, 33, 30-32.

38. GB/T 6730. 8-2016. Iron Ores-Determination of Iron (II) Content-Potassium Dichromate Titrimetric Method; China Standard Press: Beijing, China, 2017; p. 12.

39. MEP. China, Soil-Determination of Cyanide and Total Cyanide-Spectrometric Method; China Environmental Science Press: Beijing, China, 2015.

40. Phutthimethakul, L.; Kumpueng, P.; Supakata, N. Use of Flue Gas Desulfurization Gypsum, Construction and Demolition Waste, and Oil Palm Waste Trunks to Produce Concrete Bricks. Crystals 2020, 10, 709. [CrossRef]

41. Wei, L.; Zhao, S.; Liu, S.; Wang, L.; Guan, X. Effect of preparation conditions on the shape and distribution of MgO in clinker. J. Wuhan Univ. Technol. 2013, 35, 27-32. 
42. Dong, K.; Xie, F.; Chang, Y.; Chen, C.; Wang, W.; Lu, D.; Gu, X. A novel strategy for the efficient decomposition of toxic sodium cyanate by hematite. Chemosphere 2020, 256, 127047. [CrossRef]

43. Zhang, T.; Wu, C.; Li, B.; Wang, C.; Chen, X.; Wei, J.; Yu, Q. Clarifying the decomposition process of pyrite and $\mathrm{SO}_{2}$ release in the cyclone preheater of a dry rotary cement kiln system. J. Clean. Prod. 2019, 241, 118422. [CrossRef]

44. Li, L.; Wang, R.; Zhang, S. Effect of curing temperature and relative humidity on the hydrates and porosity of calcium sulfoaluminate cement. Constr. Build. Mater. 2019, 213, 627-636. [CrossRef]

45. Zhai, H.; Bian, C.; Yu, Y.; Zhu, L.; Guo, L.; Wang, X.; Yu, Q.; Zhu, J.; Cao, X. Sustainable Route for Synthesis of All-Silica SOD Zeolite. Crystals 2019, 9, 338. [CrossRef]

46. Colville, A.A.; Geller, S. The crystal structure of brownmillerite, $\mathrm{Ca}_{2} \mathrm{FeAlO}_{5}$. Acta Crystallogr. Sect. B Struct. Crystallogr. Cryst. Chem. 1971, 27, 2311-2315. [CrossRef]

47. Salasin, J.R.; Rawn, C. Structure Property Relationships and Cationic Doping in [Ca24A128O64]4+ Framework: A Review. Crystals 2017, 7, 143. [CrossRef]

48. Ceretti, M.; Corallini, S.; Paulus, W. Influence of Phase Transformations on Crystal Growth of Stoichiometric Brownmillerite Oxides: $\mathrm{Sr}_{2} \mathrm{ScGaO}_{5}$ and $\mathrm{Ca}_{2} \mathrm{Fe}_{2} \mathrm{O}_{5}$. Crystals 2016, 6, 146. [CrossRef]

49. Boyko, E.; Wisnyl, L.G. The optical properties and structures of $\mathrm{CaO}_{2} \mathrm{Al}_{2} \mathrm{O}_{3}$ and $\mathrm{SrO}_{2} \mathrm{Al}_{2} \mathrm{O}_{3}$. Acta Crystallogr. 1958, 11, 444-445. [CrossRef]

50. Natta, G.; Passerini, L. Soluzioni solide, isomorfismo e simmorfismo tra gli ossidi dei metalli bivalenti. Sistemi: CaO-CdO. CaOMnO, $\mathrm{CaO}-\mathrm{CoO}, \mathrm{CaO}-\mathrm{NiO}, \mathrm{CaO}-\mathrm{MgO}$. Gazz. Chim. Ital. 1929, 59, 129-154. (In Italian)

51. Schmahl, N.G.; Eikerling, G.F. Über Kryptomodifikationen desCu(II)-Oxids. Z. Phys. Chem. 1968, 62, 268-279. [CrossRef]

Publisher's Note: MDPI stays neutral with regard to jurisdictional claims in published maps and institutional affiliations. 